\title{
Actual Disciplinary Knowledge, Perceived Disciplinary Knowledge, Teaching Experience and Teacher's Training for Reading Instruction: A Study with Primary Portuguese and American Teachers
}

\author{
João Lopes*, Louise Spear-Swerling**, Célia Oliveira*, \\ M. Gabriela Velasquez*, and Jamie Zibulsky*** \\ *University of Minho, **Southern Connecticut University, ***Fairleigh University
}

\begin{abstract}
In this study, the relation between primary teachers' actual disciplinary knowledge and teachers' perceived disciplinary knowledge in three distinct areas of reading instruction (phonics, fluency/ vocabulary/comprehension, and assessment/intervention), as well as the relation between teachers' experience and teachers' background with these variables is investigated. Participants include Portuguese primary teachers $(n=390)$ and American primary teachers $(n=390)$. Results show that the American teachers outperform the Portuguese teachers in almost every item in analysis. Canonical correlation and commonality analysis show that actual disciplinary knowledge and perceived disciplinary knowledge are relatively independent constructs. Regression analyses show that actual knowledge predicts a small but significant amount of the variance in perceived knowledge. Knowledge about phonics instruction is by far the best unique predictor of teachers' perceived knowledge. The hypothesis of miscalibration (the "unskilled-and-unaware effect") between actual knowledge and perceived knowledge in the less knowledgeable teachers was also explored. However, results do not suggest such an effect in our participants. Results also show that there are significant differences between Portuguese and American teachers, mainly in the area of knowledge about assessment/intervention.
\end{abstract}

Keywords: Reading instruction; knowledge; perceived knowledge; miscalibration.

\section{Resumo}

Neste estudo investiga-se a relação entre conhecimento real e conhecimento percebido de professores do $1 .^{\circ}$ ciclo do ensino básico em três áreas distintas do ensino da leitura (ensino fónico, fluência/ vocabulário/compreensão e avaliação/intervenção), bem como a relação da formação e experiência dos professores com estas variáveis. Participaram no estudo 390 professores Portugueses e 390 professores Americanos. Os resultados revelam que os professores americanos superam os professores portugueses em quase todas as variáveis em análise. A análise das correlações canónicas e a análise das comunalidades mostra que o conhecimento disciplinar e a percepção de conhecimento disciplinar são constructos relativamente independentes. As análises de regressão mostram que o conhecimento disciplinar prediz uma pequena mas significativa porção da variância do conhecimento percebido, constituindo o conhecimento acerca do ensino fónico claramente o melhor preditor. Foi também explorada a hipótese da falta de calibração (o efeito "incompetente-e-inconsciente do facto") entre conhecimento e conhecimento percebido nos professores com menor nível de conhecimento. Os resultados, porém, não sugerem tal efeito nos nossos participantes. Os resultados mostram ainda a existência de diferenças significativas entre os professores Portugueses e Americanos, principalmente nos conhecimentos acerca de avaliação/intervenção.

Palavras-chave: Ensino da leitura; conhecimento; conhecimento percebido; falta de calibração.

Acknowledgements: Our special thanks to our colleagues Leandro Almeida (University of Minho) and Elaine Cheesman (University of Colorado) who are also responsible for this article.

Correspondence concerning this article should be addressed to João Lopes, Escola de Psicologia, Universidade do Minho, Campus de Gualtar, s/n, 4710-057, Braga, Portugal. Email: joaols@psi.uminho.pt 


\section{Introduction}

There is a growing consensus that effective reading instruction is a key element of reading achievement (Carreker, Joshi, \& Boulware-Gooden, 2010; Cunningham, Zibulsky, \& Callahan, 2009) and for the prevention and remediation of reading failure (González-Valenzuela, Martín-Ruiz, \& Delgado-Ríos, 2012; OECD, 2009). The International Reading Association (IRA, 2003, 2007), for instance, states that six basic elements should be included in teacher education programs: foundation in research and theory, word-level instructional strategies, text-level comprehension strategies, reading-writing connections, instructional approaches, and materials and assessment strategies. The International Dyslexia Association (IDA) (Moats et al., 2010) also stresses the importance of effective reading, and that instruction must encompass the structure of language, including phonology, orthography, morphology, syntax and semantics, as well as strategies that emphasize planning, organization, and self-management.

Researchers have found that primary teachers frequently do not seem to receive informed education about effective reading practices and that reading specialists and special education teachers are no more informed than general education teachers about specific strategies to deal with struggling readers (Moats et al., 2010; Joshi et al., 2009). Others (e.g., Jenkins, Fuchs, \& van de Broek, 2003; Moats, 2009; NRP, 2000) have stressed that teachers' knowledge about print structure, phonemic awareness and phonics instruction, reading fluency instruction, vocabulary instruction and reading comprehension instruction is critical for reading success, especially in students at risk for reading difficulties. Still others stress that knowledge about phonics or even spelling instruction may be much more critical in countries with inconsistent orthographies, like English (Seymour et al., 2003). However, to our knowledge, there are no cross-cultural studies about teachers reading knowledge in countries with consistent (e.g., Portuguese, Spanish) and less consistent (e.g., English) orthographies. Therefore we are not sure whether they show differential knowledge about different reading features (e.g., phonics, vocabulary, fluency, comprehension) or whether their knowledge should have specificities.

The relation between teachers' disciplinary knowledge and students' progress does not seem straightforward, however. Some authors suggest that this relation is complex and that teachers may not always directly apply their disciplinary knowledge when teaching reading (e.g. Carlisle, Correnti, 
Phelps, \& Zeng, 2009). Furthermore, many factors influence students' reading achievement besides teacher knowledge, including choices of instructional methods, availability of resources, and home influences on literacy (Finn \& Kanstoroom, 2001).

Anyway, teachers do not seem to be receiving or to be using much of the available researchbased disciplinary knowledge (Spear-Swerling, 2007), in part because pre-service and in-service teacher education programs do not seem to be effectively disseminating this information (EACEA, 2011; Walsh, Glaser, \& DunneWilcox, 2006). Furthermore, teachers sometimes seem to overestimate their actual knowledge about reading (Bos, Mather, Dickson, Podhajski, \& Chard, 2001; Perry, Stanovich, \& Stanovich, 2004).

Investigations of the miscalibration between people's perceived knowledge and their actual knowledge, as well as the potential consequences of this miscalibration, have been receiving increasing interest and have been conducted within the critical thinking literature (e.g., Lewis \& Smith, 1993; Sternberg, 1986; Washburn, Joshi, \& Binks-Cantrell, 2011; Willingham, 2007). The miscalibration phenomenon was formerly conceptualized by Kruger and Dunning $(1999,2002)$ and became known as the Dunning-Kruger effect (or the "un- skilled-and-unaware effect"). It has also received other names like illusory superiority, above average effect, superiority bias, etc. This framework suggests that (a) success and satisfaction in many life domains depend on knowledge and on an accurate perception of our own limitations, (b) people significantly vary on how well they succeed in applying their knowledge and wisdom in life domains and, most importantly, (c) people who are incompetent in a specific life domain tend to overestimate their knowledge and skill and that they lack the metacognitive skills to be aware of it (Dunning, 2011; Kruger \& Dunning, 1999).

Some authors challenge the idea of miscalibration. Ackerman, Beier and Bowen (2002), for instance, state that results from correlational studies involving miscalibration research show a different picture from experimental research, and that individuals are usually accurate about their skills and knowledge. Also, Krajc and Ortmann (2008) contend that flawed self-assessments originate from biased information rather than from biased judgments, and that Dunning and Kruger generally sampled students who were naïve about the knowledge required to perform the experimental tasks. Therefore, they could not make accurate judgments about that knowledge.

Although this paradigm has been tested with a number of popu- 
lations, to our knowledge it has not yet been addressed with teachers in the area of reading instruction (who may or may not receive specific feedback about their performance). Nevertheless, in the last ten years, several studies in the area of reading instruction have examined teachers' disciplinary knowledge and teachers' perceived knowledge (e.g., Spear-Swerling, Brucker, \& Alfano, 2005; Walsh et al., 2006). Cunningham et al. (2004) found that their subjects were able to accurately calibrate their knowledge in the area of children's literature but not in the domains of phoneme awareness and phonics. More interesting, they found that less experienced and less credentialed teachers perceived themselves as more knowledgeable than more experienced teachers.

Some researchers (e.g., Finn \& Kanstoroom, 2001; Walsh et al., 2006) suggest that the miscalibration of teachers' perceived knowledge and teachers' disciplinary knowledge, may have to do with the fact that teacher training in the area of reading instruction is often not approached scientifically. In one of the most important studies about elementary teachers' education schools in the USA, Walsh et al. (2006) concluded that "most education schools are not teaching the science of reading" (p. 22), that "much of current reading instruction is incompatible with science" (p. 29), and that "teacher educators portray the science of reading instruction as an approach that is no more valid than others" (p. 30). If undergraduate teachers are not receiving appropriate instruction, one can hardly expect them to be able to calibrate their perceived knowledge with the needed disciplinary knowledge (Applegate \& Applegate, 2004; Binks-Cantrell, Washburn, Joshi, \& Hougen, 2012).

Knowledge calibration is important because people are more likely to engage in specific actions and to be more self-determined when they are aware of their limited knowledge in a specific area (Cunningham et al., 2009; Deci \& Ryan, 2008). This may have important implications in the area of reading instruction because teachers who erroneously believe to have a thorough knowledge of reading instruction may not seek out or be receptive to further professional development in reading.

\section{The present study}

We compared actual disciplinary knowledge and perceived disciplinary knowledge in a group of American and in a group of Portuguese primary teachers, in relation to their experience and preparation. Teachers' disciplinary knowledge and teachers' perceived knowledge in several domains of reading instruction (e.g., phonics, vocabulary knowledge) were ex- 
amined. The main questions of the study are:

1. Do Portuguese and American teachers differ in perceived knowledge and in disciplinary knowledge?

2. Do teachers' experience, teachers' training and teachers' disciplinary knowledge predict teachers' perceived knowledge?

3. Do less knowledgeable teachers show an overly optimistic perspective about their knowledge when compared with more knowledgeable teachers?

\section{Method}

\section{Participants}

Three hundred and ninety Portuguese and 390 American primary teachers participated in this study. Portuguese participants come from a stratified sample of an initial pool of 2,461 teachers that volunteered to the study. This sample is representative of eight regions of the country (North coast, North interior, Center, Lisbon and Tejo Valley, Alentejo, Algarve, and Atlantic Islands). American teachers come from three different states (Connecticut, $n=97$; Colorado, $n=46$; and New Jersey, $n=181$ ). All teachers were individually contacted by the researchers and all volunteered to participate. Both in Portugal and in the USA it is expected that primary teachers are aware of the reading features that must be taught along the primary school years (e.g., decoding, fluency, comprehension). Demographic information about participants is displayed in Table 1 .

Data show that the Portuguese teachers have more experience than the American teachers, $U=-14.75, p<.001, r=-.02$, but their training level is lower, $U=-13.45, p<.001, r=-.02$. The small effect sizes suggest that differences between these samples are not practically significant. Participants are teaching first grade (25\%), second grade $(20 \%)$, third grade $(23 \%)$ and fourth grade students $(32 \%)$.

\section{Measures}

\section{Teachers' Knowledge Survey (TKS)}

The original English version of the TKS was modeled after the multiple-choice section of a teacher licensure exam used in several U. S. states, the Foundations of Reading Test (FRT), published by Evaluation Systems Group of Pearson. The FRT employs items that assess knowledge about all five components of reading - phonemic awareness, phonics, fluency, vocabulary, and comprehension as well as assessment. Altogether there were 52 multiple-choice items in the English version of the study survey, with about one-third of items assessing basic content 
Table 1

Demographic Information about Participants

\begin{tabular}{lcccc}
\hline & $\begin{array}{c}\text { Portuguese } \\
\text { teachers }\end{array}$ & $\begin{array}{c}\text { American } \\
\text { teachers }\end{array}$ & TOTAL & $\%$ \\
\hline$N$ & 390 & 390 & 780 & \\
\hline Gender & & & & \\
$\quad$ Male & 49 & 50 & 99 & 12.69 \\
$\quad$ Female & 341 & 340 & 681 & 87.31 \\
\hline Teaching Experience* & $M=19$ & $M=7.7$ & & \\
(years) & $(D P=9.86)$ & $(D P=9.34)$ & & \\
$\quad$ Low experience (0-5) & 31 & 211 & 242 & 31.80 \\
Regular experience (6-15) & 139 & 100 & 239 & 31.40 \\
Fair experience (16-25) & 98 & 33 & 131 & 17.20 \\
$\quad$ High experience (+25) & 122 & 27 & 149 & 19.60 \\
\hline Teacher's training & & & & \\
$\quad$ Bachelor & 31 & 7 & 38 & 4.87 \\
Licensure & 302 & 230 & 532 & 68.21 \\
Master & 55 & 151 & 206 & 26.41 \\
$\quad$ Beyond Master & 2 & 2 & 4 & .51 \\
\hline
\end{tabular}

Note- $M=$ Mean; $S D=$ Standard Deviation.

* Number of years as a primary teacher.

knowledge about reading, and the remaining two-thirds assessing application of content knowledge. Each item had a stem and 4 multiple-choice options, along with a fifth alternative, "I don't know." All questions had only one correct answer. A more detailed description of the TKS, including sample items, can be found in Spear-Swerling and Cheesman (2012).

The 52 items can be grouped in three clusters: Phonemic Awareness/Phonics (PA/PHO) (23 items), (Cronbach's $\alpha=.60$ for the American version of the questionnaire;
.70 for the Portuguese version); Fluency, Vocabulary, and Comprehension (FLU/VOC/COMP), (20 items) $(\alpha=.69$ and .85 respectively), and Assessment/Intervention (ASSI), (9 items), $(\alpha=.75)$.

\section{Teachers' Self-Rating Scale (TSRS)}

For the self-ratings, participants were asked to evaluate their own knowledge in different areas on a scale from 1 to 5 , where 1 was defined as "very limited knowledge," 3 as a "moderate level of 
knowledge," and 5 as a "very high level of knowledge." There were 13 ratings areas in total. These included self-ratings of knowledge for teaching the five components of reading (phonemic awareness, phonics, fluency, vocabulary, comprehension), as well as knowledge about other areas important to providing effective reading instruction (e.g., norm-referenced testing, building children's motivation to read, interventions for struggling readers in general).

For both the American and the Portuguese version of the scale ( $\alpha=.93)$, items can be clustered in "Perceived knowledge about Phonemic Awareness/Phonics," ( $\alpha=.86)$ "Perceived knowledge about Fluency/Vocabulary/Comprehension" $(\alpha=.88)$, and "Perceived knowledge about Assessment/Intervention" $(\alpha=.68)$.

\section{Procedure}

The American participants were recruited from both university settings, involving graduatelevel classes in teacher education programs, and public school settings. They received paper-andpencil versions of the study measures, administered in groups, with supervision from a research assistant or one of the investigators. All measures were administered in a single session that took approximately one hour to seventy-five minutes. Participants completed the self-ratings, along with a ques- tionnaire that elicited information about their teaching experience and educational background, prior to taking the Teacher Knowledge Survey. Portuguese participants filled online versions of all the questionnaires in a Survey Monkey platform. Every questionnaire should be completely filled so that the next questionnaire could be accessed. The filling time was electronically recorded for every participant. Participants spent about one-hour filling the questionnaires.

\section{Results}

\section{Teachers' knowledge and teachers' perceived knowledge}

Table 2 shows a descriptive statistics of the results in the TKS and in the TSRS, and the variance ratio.

Differences were found between countries for all features of disciplinary knowledge. Notably the only difference in perceived knowledge involves PKASSI, with Portuguese teachers perceiving themselves as more knowledgeable than American teachers about assessment and intervention, $t(778)=-12.63, p<.001$, $r=.26$. Paradoxically, this is by far the area of disciplinary knowledge (KASSI) where Portuguese teachers perform worst and where differences between the two countries, favoring American teachers, 
Table 2

Teachers' Knowledge and Teachers' Perceived Knowledge

\begin{tabular}{|c|c|c|c|c|}
\hline & $\begin{array}{c}\text { American } \\
\text { teachers }\end{array}$ & & $\begin{array}{c}\text { Portuguese } \\
\text { teachers }\end{array}$ & \\
\hline \multirow{4}{*}{ PKPA } & $\begin{array}{l}M \\
S D\end{array}$ & $\begin{array}{c}3.41 \\
(1.22)\end{array}$ & & $\begin{array}{c}3.32 \\
(0.81)\end{array}$ \\
\hline & $t$ & & 1.282 & \\
\hline & $p$ & & .200 & \\
\hline & $V R^{* *}$ & & 2.27 & \\
\hline \multirow{4}{*}{ PKFVC } & $\begin{array}{c}M \\
S D\end{array}$ & $\begin{array}{c}3.51 \\
(1.15)\end{array}$ & & $\begin{array}{c}3.62 \\
(0.70)\end{array}$ \\
\hline & $t$ & & -1.623 & \\
\hline & $p$ & & .105 & \\
\hline & $V R^{* *}$ & & 2.70 & \\
\hline \multirow{4}{*}{ PKASSI } & $\begin{array}{c}M \\
S D\end{array}$ & $\begin{array}{c}2.58 \\
(1.00)\end{array}$ & & $\begin{array}{c}3.37 \\
(070)\end{array}$ \\
\hline & $t$ & & -12.628 & \\
\hline & $p$ & & $.001 * * *$ & \\
\hline & $V R^{* *}$ & & 2.00 & \\
\hline \multirow{5}{*}{ PKnow. Total } & $M$ & 3.30 & & 3.47 \\
\hline & $S D$ & (1.11) & & \\
\hline & $t$ & & -2.464 & \\
\hline & $p$ & & .014 & \\
\hline & $V R^{* *}$ & & 2.66 & \\
\hline \multirow{4}{*}{ KPA } & $M$ & 54.43 & & $\begin{array}{c}43.44 \\
(14.40)\end{array}$ \\
\hline & $\begin{array}{c}S D \\
t\end{array}$ & $(19.40)$ & 8.94 & $(14.40)$ \\
\hline & $p$ & & $.001^{* * * *}$ & \\
\hline & $V R^{* *}$ & & 1.82 & \\
\hline \multirow{5}{*}{ KFVC } & $M$ & 59.35 & & 44.80 \\
\hline & $S D$ & $(15.82)$ & & (17.30) \\
\hline & $t$ & & 12.23 & \\
\hline & $p$ & & $.001 * * *$ & \\
\hline & $V R^{* *}$ & & .87 & \\
\hline \multirow{5}{*}{ KASSI } & $M$ & 46.15 & & 15.40 \\
\hline & $S D$ & (19.34) & & (12.45) \\
\hline & $t$ & & 26.28 & \\
\hline & $p$ & & $.001 * * *$ & \\
\hline & $V R^{* *}$ & & 1.68 & \\
\hline \multirow{5}{*}{ Know. Total } & $M$ & 53.04 & & 34.55 \\
\hline & $S D$ & (15.92) & & (11.70) \\
\hline & $t$ & & 18.46 & \\
\hline & $p$ & & $.001^{* * *}$ & \\
\hline & $V R^{* *}$ & & 1.80 & \\
\hline
\end{tabular}

Note. ${ }^{* *} p<.01 * * * ; p<.001$ 
PKPA: Perceived Knowledge about Phonemic Awareness and Phonics; PKFVC: Perceived Knowledge about Fluency, Vocabulary, Comprehension; PKASSI: Perceived Knowledge about Assessment and Intervention; KPA: Knowledge about Phonemic Awareness and Phonics; KFVC: Knowledge about Fluency, Vocabulary, Comprehension; KASSI: Knowledge about Assessment and Intervention;

Perceived knowledge: Min - 1, Max - 5; Knowledge: Min - 0, Max - 100 (percent corrects)

* VR: Variance Ratio. With the exception of KFVC, variances are unequal. Since inequality is most likely when sample size is large, Hartley's $F_{\mathrm{Max}}$ was computed. The fact that the variance ratio for every factor is $<3$ indicates that groups' variances are homogenous.

are large, $t(778)=26.28, p<.001$, $r=.46$.

\section{Relations between teachers' knowledge, teachers' training, teachers' experience and teachers' perceived knowledge}

To study the relations between (a) teachers' knowledge, teachers' training and teachers' experience, and (b) teachers' perceived knowledge, a canonical correlation analysis was conducted. For this analysis both samples (Portuguese and American teachers) are considered altogether. The three knowledge variables, the degree (level) of teacher training, and the years of experience, were used as predictors, and the three perceived knowledge features as criterion variables, to evaluate the multivariate shared relationship between the two variable sets (i.e., Knowledge/Degree/Experience and Perceived Knowledge). The analysis yielded three functions with squared canonical correlations of
$.163, .119$, and .007 for each successive function. Collectively, the full model across all functions was statistically significant using the Wilks's $\lambda=.731$ criterion, $\chi^{2}(15)=242.470, p<.001 . \mathrm{Be}-$ cause Wilks's $\lambda$ represents the variance unexplained by the model, $1-\lambda$ yields the full model effect size in an $r^{2}$ metric. Thus, for the set of three canonical functions, the $r^{2}$ type effect size is .269 , which indicates that the full model explains about $27 \%$ of the variance shared between the variable sets.

The dimension reduction analysis shows that the full model (Functions 1 to 3 ) is statistically significant, and that Function 2 to 3 is also statistically significant, $c^{2}(8)=104.372, p<.001$. Function 3 does not explain a statistically significant amount of shared variance between the variable sets, $c^{2}(3)=5.999$, n.s. Table 3 presents only the standardized canonical function coefficients and structure coefficients for the statistically 
Table 3

Canonical Correlation Results

\begin{tabular}{|c|c|c|c|c|c|c|}
\hline \multirow{2}{*}{$\begin{array}{l}\text { Full Model } \\
\text { Evaluation }\end{array}$} & \multicolumn{6}{|c|}{ Origin of the Effect } \\
\hline & \multicolumn{3}{|c|}{ Predictor Set } & \multicolumn{3}{|c|}{ Criterion Set } \\
\hline Wilks's $\lambda$ & \multicolumn{3}{|c|}{ Raw Canonical Coefficients } & \multicolumn{3}{|c|}{ Raw Canonical Coefficients } \\
\hline Function 1 Function 2 & & Function 1 & Function 2 & & Function 1 & Function 2 \\
\hline .731 & $\begin{array}{l}\text { T.Train } \\
\text { YrsExper } \\
\text { KPA } \\
\text { KFVC } \\
\text { KASSI }\end{array}$ & $\begin{array}{r}.168 \\
-.307 \\
-.028 \\
-.022 \\
-.045\end{array}$ & $\begin{array}{l}-.455 \\
-.349 \\
-.038 \\
-.009\end{array}$ & $\begin{array}{l}\text { PKPA } \\
\text { PKFVC } \\
\text { PKASSI }\end{array}$ & $\begin{array}{r}.196 \\
.056 \\
-1.154\end{array}$ & $\begin{array}{r}-.889 \\
-.261 \\
.313\end{array}$ \\
\hline \multicolumn{7}{|l|}{ Function 1 Function 2} \\
\hline \multirow[t]{2}{*}{242.470} & \multicolumn{3}{|c|}{ Std. Canonical Coefficients } & \multicolumn{3}{|c|}{ Std. Canonical Coefficients } \\
\hline & \multicolumn{3}{|c|}{ Function 1 Function 2} & \multicolumn{3}{|c|}{ Function 1 Function 2} \\
\hline $\mathrm{df}$ & T.Train & .089 & -.242 & PKPA & .202 & -.914 \\
\hline Function 1 Function 2 & YrsExper & -.250 & -.285 & PKFVC & .053 & -.247 \\
\hline 15 & $\begin{array}{l}\text { KPA } \\
\text { KFVC } \\
\text { KASSI }\end{array}$ & $\begin{array}{r}-.516 \\
-.404 \\
-1.178\end{array}$ & $\begin{array}{l}-.690 \\
-.045 \\
-.243\end{array}$ & PKASSI & -1.088 & .295 \\
\hline $\mathrm{R}_{\mathrm{c}}$ & \multicolumn{3}{|c|}{ Structure Coefficients } & \multicolumn{3}{|c|}{ Structure Coefficients } \\
\hline Function 1 Function 2 & & Function 1 & Function 2 & & Function 1 & Function 2 \\
\hline .404 & $\begin{array}{l}\text { T.Train } \\
\text { YrsExper } \\
\text { KPA } \\
\text { KFVC } \\
\text { KASSI }\end{array}$ & $\begin{array}{l}-.018 \\
-.597 \\
-.519 \\
-.244 \\
-.317 \\
\end{array}$ & $\begin{array}{r}.587 \\
-.026 \\
.712 \\
.606 \\
.852 \\
\end{array}$ & $\begin{array}{l}\text { PKPA } \\
\text { PKFVC } \\
\text { PKASSI }\end{array}$ & $\begin{array}{r}-.675 \\
-.676 \\
.968\end{array}$ & $\begin{array}{r}.734 \\
.383 \\
-.326\end{array}$ \\
\hline Function 1 Function 2 & \multicolumn{3}{|c|}{ Squared Structure Coefficients } & \multicolumn{3}{|c|}{ Squared Structure Coefficients } \\
\hline \multirow[t]{2}{*}{.163} & & Function 1 & Function 2 & & Function 1 & Function 2 \\
\hline & $\begin{array}{l}\text { T.Train } \\
\text { YrsExper } \\
\text { KPA } \\
\text { KFVC } \\
\text { KASSI }\end{array}$ & $\begin{array}{l}.067 \\
.187 \\
.012 \\
.012 \\
.526\end{array}$ & $\begin{array}{l}.203 \\
.088 \\
.801 \\
.487 \\
.389\end{array}$ & $\begin{array}{l}\text { PKPA } \\
\text { PKFVC } \\
\text { PKASSI }\end{array}$ & $\begin{array}{l}.034 \\
.106 \\
.937\end{array}$ & $\begin{array}{l}.949 \\
.545 \\
.063\end{array}$ \\
\hline
\end{tabular}

Note. Wilks's $\Lambda, \chi^{2}$, and $d f$ noted as Function 1 are the statistics associated with Canonical Functions 1-2 (the full model). Wilks's $\Lambda, \chi^{2}$, and $d f$ noted as Function 2 are the statistics associated with Canonical Function 2 in isolation. Std. = Standardized. 
significant functions (Functions 1 and 2).

Function 1 coefficients show that perceived knowledge of assessment and intervention (PKASSI) is the most relevant criterion variable. This conclusion is supported by the squared structure coefficients. This variable also has by far the largest canonical function coefficient. The low structure coefficients and moderate to high standard coefficients of KPA suggest that this variable serves as a suppressor in the canonical effect. Also, the low standardized function coefficient, alongside a moderate to high structure coefficient of KFVC, indicates that this variable contributes little unique variance to the canonical effect and that much of the variable's contribution is also explained by another variable or variables.

Moving to Function 2, the coefficients in Table 3 suggest that all the criterion variables are relevant for this function. Looking at the structure coefficients for the entire function it was found that all three knowledge variables are strongly positively related to PKPA and to PKFVC.

Given the results of the canonical correlation analysis, a regression commonality analysis was conducted to further explore the unique and the common contribution of the predictors to teachers' perceived knowledge. For our analysis we used KPA, KFVC, KASSI, Teacher Training (T. Train), and the
Years of Experience (YrsExper) as predictors, and a composite measure of Teachers' Perceived Knowledge as a criterion (PKPA + PKFVC + PKASSI). Since the use of five predictors makes the procedure complex, because of the number of coefficients and equations $\left(2^{k}-1\right.$, where $k$ is the number of predictor variables) involved, we adopted the suggestion of $\mathrm{Ni}$ mon (2010) and we have computed results using two separate sets of related predictor variables: teachers' training and years of experience on one set and knowledge related variables (KPA, KFVC, KASSI) on another set. Results are shown in Tables 4 and 5.

\section{Do less knowledgeable teachers show an overly optimistic perspective about their knowledge (the "unskilled and unaware effect")?}

To answer this research question, we organized the data in a similar way to classical studies in this area (e.g., Krajc \& Ortmann, 2008; Kruger \& Dunning, 1999). First, participants were grouped in quartiles (bottom, $2^{\text {nd }}, 3^{\text {rd }}$ and top) according to their performance in the TKS (Teachers' Knowledge Survey) (predictor variable). Every teacher's quartile in the TKS was then compared to his/her quartile in the TSRS (Teachers' Self-Rating Scale) (criterion variable) to check whether the teacher's actual knowledge and the teacher's per- 
Table 4

Regression Results and Commonality Coefficients

\begin{tabular}{lcccrrrrrrr}
\hline Predictor $(x)$ & $R$ & $R^{2}$ & $R_{a d j}^{2}$ & \multicolumn{1}{c}{$\beta$} & $P$ & $r_{s}$ & Unique & Common & Total & $\%$ de $R^{2}\left(r_{s}^{2}\right)$ \\
\hline & .33 & .11 & .11 & & & & & & & \\
KPA & & & & .32 & $<.001$ & .74 & .050 & .01 & .06 & 49.95 \\
KFVC & & & & .14 & .010 & .28 & .007 & .02 & .03 & 7.01 \\
KASSI & & & & -.26 & $<.001$ & .59 & .035 & -.04 & .00 & 32.25 \\
\hline
\end{tabular}

Note. Unique $=x$ 's unique effect. Common $=\Sigma x$ 's common effects. Total $=$ Unique + Common.

Table 5

Regression Results and Commonality Coefficients

\begin{tabular}{lcccccccccc}
\hline Predictor $(x)$ & $R$ & $R^{2}$ & $R_{\text {adj }}^{2}$ & $\beta$ & $P$ & $r_{s}$ & Unique & Common & Total & $\%$ de $R^{2}\left(r_{s}{ }^{2}\right)$ \\
\hline & .20 & .04 & .04 & & & & & & & \\
T.Train & & & & .05 & .18 & .24 & .00 & .00 & .00 & 5.81 \\
YrsExper. & & & & .19 & $<.001$ & .92 & .03 & .00 & .03 & 85.01 \\
\hline
\end{tabular}

Note. Unique $=x$ 's unique effect. Common $=\Sigma x$ 's common effects. Total $=$ Unique + Common.

ceived knowledge match or mismatch, and to check how strong the mismatch is, if any. Since the results of the Portuguese and of the American teachers on the TKS are significantly different, we examined both the aggregate and the disaggregated results of both samples.

Results for misclassification only are shown is Graphs 1 and 2. Graph 1 shows how teachers (American and Portuguese), divided by quartiles of performance in the TKS, (mis)classified themselves in the TSRS. Graph 2 exhibits the same information for American and Portuguese teachers separately. The crosstabulation of the teachers' performance in the TSK and in the TSRS shows that both bottom and top performers in the TSK, more accurately classify their own knowledge than teachers in the $2^{\text {nd }}$ and in the $3^{\text {rd }}$ quartile. This is true for both Portuguese and American teachers.

\section{Discussion}

First, we must note that results show that American teachers significantly outperform Portuguese teachers in every feature of disciplinary knowledge. However, effect sizes for KPA $(r=.09)$ and for $\operatorname{KFVC}(r=.14)$ are small. The 


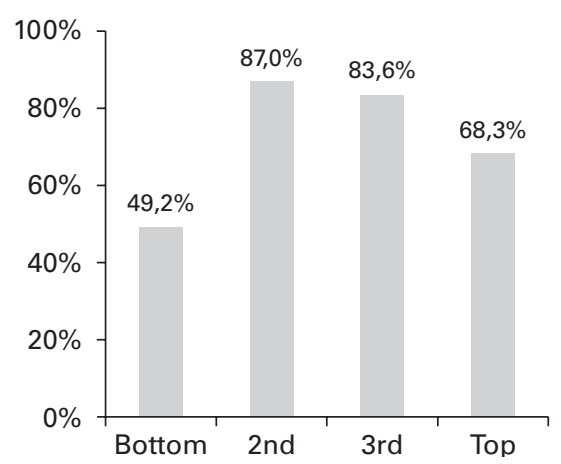

Graph 1. Misclassification - All teachers.

only meaningful effect size is for KASSI $(r=.46)$. At the same time, results show that the perceived disciplinary knowledge is identical for PKPA and for KFVC, but not for PKASSI (though with a small effect size, $r=.17)$. In this case, the Portuguese teachers perceive themselves as more competent than the American teachers. As we previously stated this finding is somewhat paradoxical since this (KASSI) is the domain where the Portuguese teachers perform the worst. Accountability for students' progress is however much recent in Portugal and eventually teachers do not yet feel the need to systematically assess and intervene with underachievers (Lopes, 2012).

Even if the results of American and Portuguese teachers reflect actual between- groups' differences in knowledge, the interpretation of such differences is not straightforward. On the one hand,

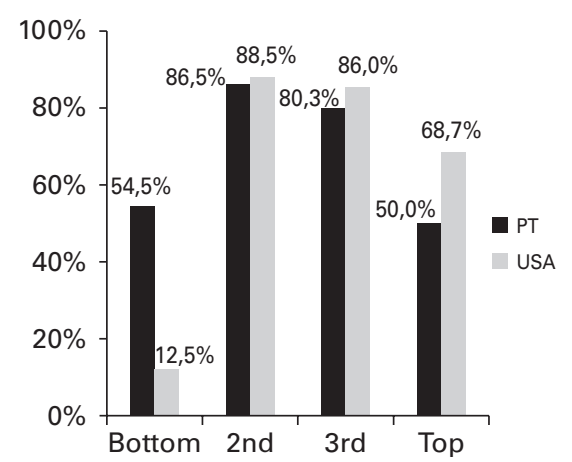

Graph 2. Misclassification - American vs Portuguese teachers.

some of the knowledge required to perform well on the TKS is more likely taught in teacher education programs in the USA than in Portugal, a country where the "science of reading" literature is not yet widely known (Lopes, 2010). On the other hand, some of the knowledge required by the TKS - most notably knowledge related to phonics - may be critical for the teaching of reading in an inconsistent, deep orthography like English, but not necessarily in an intermediate depth orthography like Portuguese (Sucena, Castro, \& Seymour, 2009). This argument is controversial, however. Some authors (e.g., Seymour et al., 2003) claim that European Portuguese is closer to inconsistent European orthographies like English, French or Danish, than to relatively shallow orthographies like Finish, Italian or Spanish; others (e.g., Sucena et al., 2009) believe that there are a 
number of linguistic features suggesting that the European Portuguese is an orthography of intermediate depth.

The underperformance of the Portuguese teachers in the TKS may also have to do with the fact that a significant number of these teachers have high experience (i.e., they are older). A number of them may therefore be less familiar with some of the concepts (e.g., phonemic awareness) approached in the questionnaire. Rather, their greater experience can make them feel more confident in their knowledge, thus explaining their higher results in the TSRS.

Also noteworthy are the striking differences in KASSI between American and Portuguese teachers. Indeed Portuguese teachers' performance on this subscale $(18 \%$ success) is extremely poor even when compared to their own performance on the other subscales. Since knowledge about the "science of reading" is not yet systematically taught in Portugal, we anticipated some problems with the subscale of KPA and with some items of KFVC, but not particularly with the items of KASSI. We can speculate that because the notion of accountability for students' results is most recent in the Portuguese educational system, teachers still lack the knowledge to assess and to monitor students' progress and difficulties within the classroom context.

It was also our purpose to investigate the relation between teachers' perceived knowledge and teachers' disciplinary knowledge. The canonical correlation analysis (CCA) and the commonality analysis showed that actual knowledge and perceived knowledge are relatively independent factors. The analysis also showed that there is much common variance shared by knowledge related variables (KPA, KFVC and KASSI) in the prediction of global perceived knowledge, and that there are suppression effects between variables. Although these results are similar to those found by others (e.g., Binks-Cantrell et al., 2012; Washburn et al., 2011), the large overlap between KPA, KFVC and KASSI, suggests that these variables represent one single factor. It seems therefore meaningless to explain the predictive value of any specific knowledge variables. Anyway, regression results show that teachers' knowledge is a significant predictor of teachers' perceived knowledge (better than teachers' experience and much better than teachers' training). Yet, still other factors may account for the gap between knowledge and perceived knowledge. Eventually primary teachers seldom receive feedback about their knowledge (McCutchen et al., 2002) and they may also not be fully aware of reading instruction requirements (Lopes, 2010; NRP, 2000).

The results from our study also show that teachers' initial training does not predict teachers' perceived 
knowledge, but years of teaching experience do. Taking into account that our subjects' age ranges from 23 to 57 , we must acknowledge that much has changed in teachers' certification level along three decades (Walsh et al., 2006; European Commission, 2010). Yet it may be that even if our older participants hold lower academic degrees than their younger counterparts, this doesn't necessarily suggest lower academic qualifications. As Carlisle et al., (2009) stress, “...master's degree programs vary widely in the content and formats for learning about reading, so that attainment of this degree does not signal acquisition of a particular kind or depth of knowledge about early reading" (p. 475). This may partly explain why teachers' training does not predict teachers' perceived knowledge.

The fact that older participants are more confident about their knowledge suggests that teachers' experience is positively involved in teachers' perceived knowledge and also in teachers' self-efficacy (Alderman \& Nix, 1997). This relation is not straightforward, however. Klassen and Chiu (2010), for instance, found that teachers' experience showed nonlinear relationships with self-efficacy, increasing from early career to midcareer, and then falling afterwards. There is anyway a good deal of agreement on the effect of teachers' experience on teachers' selfconfidence, teachers' self-efficacy and teachers' perceived knowledge (e.g., Egyed \& Short, 2006; SpearSwerling et al., 2005). Our results seem to moderately confirm this effect.

Finally, it was our purpose to investigate whether less knowledgeable teachers are overly optimistic about their knowledge when compared with more knowledgeable teachers (the unskilled-andunaware effect). Our results do not suggest an unskilled-and-unaware effect or overconfidence effect (Arkes, Christensen, Lai, \& Blumer, 1987; Brenner, Koehler, Liberman, \& Tversky, 1996; Griffin \& Varey, 1996). Indeed our bottom and our top knowledge teachers are the most accurate classifiers of their own knowledge $\left(2^{\text {nd }}\right.$ and $3^{\text {rd }}$ quartile teachers are by far less accurate).

Critics of the overconfidence effect (e.g., Krajc \& Ortmann, 2008) have stressed that there might be significant differences between person oriented-tasks, general knowledge tasks and skill oriented-tasks (such as those used in our study), and Krajc, Ortmann, and Ryvkin (2009) showed, in a series of experiments, that information improves calibration, especially of the unskilled subjects. In studies like ours, where participants are supposed to have a good knowledge of the subject about which they are being asked, the miscalibration is therefore unlikely. Also, Burson, Larrick, and Klayman (2006) state that the degree 
of overconfidence relates to task difficulty. The authors found results similar to those of Kruger and Dunning (1999) for easier tasks, but not for more difficult tasks.

Unfortunately in our study it was not possible to manipulate the perceived task difficulty by reversing the order of the questionnaires. That would eventually make participants perceive the task as more difficult than they formerly thought, and ultimately grown to be less optimistic about their knowledge. This is anyway a hypothesis to be tested in future studies.
Overall our results suggest that research about the miscalibration hypothesis in specific populations like primary teachers is encouraging. However there's still much to understand about the relation between knowledge and perceived knowledge and, most of all, about how to determine "how much is too much" in miscalibration. The advance of research in this area will enable teachers, schools, and even the large educational system, to fill the teaching gap and enhance reading instruction, the most basic skill for academic achievement (NRP, 2000). 


\section{References}

Ackerman, P. L., Beier, M. E., \& Bowen, K. R. (2002). What we really know about our abilities and our knowledge. Personality and Individual Differences, 33(4), 587-605. doi: 10.1016/S0191-8869(01)00174-X

Alderman, G. L., \& Nix, M. (1997). Teachers' intervention preferences related to explanations for behavior problems, severity of the problem, and teacher experience. Behavioral Disorders, 22(2), 87-95.

Applegate, A. J., \& Applegate, M. D. (2004). The Peter Effect: Reading habits and attitudes of preservice teachers. The Reading Teacher, 57(6), 554-563.

Arkes, H. R., Christensen, C., Lai, C., \& Blumer, C. (1987). Two methods of reducing overconfidence. Organizational Behavior and $\mathrm{Hu}$ man Decision Processes, 39, 133144.

Binks-Cantrell, E., Washburn, E. K., Joshi, R. M., \& Hougen, M. (2012). Peter effect in the preparation of reading teachers. Scientific Studies of Reading, 16(6), 526-536. doi: 10.1080/10888438.2011.601434

Bos, C., Mather, N., Dickson, S., Podhajski, B., \& Chard, D. (2001). Perceptions and knowledge of preservice and inservice educators about early reading instruction. Annals of Dyslexia, 51, 97-120. doi: 10.1007/ s11881-001-0007-0

Brenner, L. A., Koehler, D. J., Liberman, V., \& Tversky, A. (1996). Overconfidence in probability and frequency judgments: A critical examination. Organizational Behavior and Human Decision Processes, 65, 212-219.
Burson, A. K., Larrick, P. R., \& Klayman, J. (2006). Skilled or unskilled, but still unaware of it: how perceptions of difficulty drive miscalibration in relative comparisons. Journal of Personality and Social Psychology, 90, 60-77.

Carlisle, J. F., Correnti, R., Phelps, G., \& Zeng, J. (2009). Exploration of the contribution of teachers' knowledge about reading to their students' improvement in reading. Reading and Writing, 22(4), 457-486. doi: 10.1007/s11145-009-9165-y

Carreker, S., Joshi, R. M., \& BoulwareGooden, R. (2010). Spelling-related teacher knowledge: The impact of professional development on identifying appropriate instructional activities. Learning Disability Quarterly, 33(3), 148-158.

Cunningham, A. E., Perry, K. E., Stanovich, K. E., \& Stanovich, P. J. (2004). Disciplinary knowledge of K-3 teachers and their knowledge calibration in the domain of early literacy. Annals of Dyslexia, 54(1), 139-167.

Cunningham, A. E., Zibulsky, J., \& Callahan, M. D. (2009). Starting small: Building preschool teacher knowledge that supports early literacy development. Reading and Writing, 22, 487-510. doi: 10.1007/s11145009-9164-Z

Deci, E. L., \& Ryan, R. M. (2008). Facilitating optimal motivation and psychological well-being across life's domains. Canadian Psychology, 49(1), 14-23. doi: 10.1037/0708-5591.49.1.14

Dunning, D. (2011). The dunningkruger effect. On being ignorant of 
one's own ignorance. Advances in Experimental Social Psychology, 44, 247-296.

EACEA (2011). Teaching Reading in Europe: Contexts, Policies and Practices. Brussels: Eurydice.

Egyed, C. J., \& Short, R. J. (2006). Teacher self-efficacy, burnout, experience and decision to refer a disruptive student. School Psychology International, 27(4), 462-474. doi: $10.1177 / 0143034306070432$

European Comission (2010). Developing coherent and system-wide induction programmes for beginning teachers: a handbook for policymakers. E. Comission (Ed.) Retrieved from http://ec.europa.eu/ education/school-education/doc/ handbook0410_en.pdf

Finn, C. E., \& Kanstoroom, M. (2001). Getting better teachers: Time for experimentation. In M. C. Wang \& H. J. Walberg (Eds.), Tomorrow's teachers (pp. 149-173). Richmond, CA: McCutchan.

González-Valenzuela, M. J., Martín-Ruiz, I., \& Delgado-Ríos, M. (2012). Teaching literacy and decreased risk of learning disabilities. Revista de Psicodidactica, 17(2), 253-268. doi: 10.1387/Rev.Psicodidact.4496

Griffin, D. W., \& Varey, C. A. (1996). Towards a consensus on overconfidence. Organizational Behavior and Human Decision Processes, 65, 227-331.

IRA (2003). Teaching all children to read: The roles of the reading specialist. A position statement of the International Reading Association. Newark, DE: IRA.

IRA (2007). Teaching reading well: A synthesis of the International Reading Association's research on teacher preparation for reading instruction. Newark, DE: IRA.

Jenkins, J. R., Fuchs, L. S., \& van den Broek, P. (2003). Sources of individual differences in reading comprehension and reading fluency. Journal of Educational Psychology, 13(4), 719-729.

Joshi, R. M., Binks, E., Hougen, M., Ocker-Dean, E., Graham, L., \& Smith, D. (2009). Teachers' knowledge of basic linguistic skills: Where does it come from? In S. Rosenfield \& V. Berninger (Eds.), Handbook on implementing evidence based academic interventions (pp. 851-877). New York: Oxford University Press.

Klassen, R. M., \& Chiu, M. M. (2010). Effects on teachers' self-efficacy and job satisfaction: Teacher gender, years of experience, and job stress. Journal of Educational Psychology, 102(3), 741-756. doi: 10.1037/ a0019237

Krajc, M., \& Ortmann, A. (2008). Are the unskilled really that unaware? An alternative explanation. Journal of Economic Psychology, 29(5), 724-738. doi: 10.1016/j. joep.2007.12.006

Krajc, M., Ortmann, A., \& Ryvkin, D. (2009). How to undo biased self-assessments. Retrieved from https://iweb.cerge-ei.cz/pdf/gdn/ RRCVIII_85_paper_01.pdf

Kruger, J., \& Dunning, D. (1999). Unskilled and unaware of it: How difficulties in recognizing one's own incompetence lead to inflated selfassessment. Journal of Personality and Social Psychology 77, 11211134.

Kruger, J., \& Dunning, D. (2002). Unskilled and unaware - But why? A reply to Krueger and Mueller. Jour- 
nal of Personality and Social Psychology, 82, 189-192.

Lewis, A., \& Smith, D. (1993). Defining higher order thinking. Theory into Practice, 32(3), 131-137.

Lopes, J. A. (2010). Conceptualização, avaliação e intervenção nas dificuldades de aprendizagem: A sofisticada arquitectura de um equívoco. Braga: Psiquilíbrios.

Lopes, J. (2012). Biologising reading problems: the specific case of dyslexia. Contemporary Social Science, 7(2), 215-229. doi: 10.1080/21582041.2012.692098

McCutchen, D., Harry, D. R., Cox, S., Sidman, S., Covill, A. E., \& Cunningham, A. E., (2002). Reading teachers' knowledge of children's literature and English phonology. Annals of Dyslexia, 52(1), 205-228. doi: 10.1007/s11881-002-0013-x

Moats, L. (2009). Knowledge foundations for teaching reading and spelling. Reading and Writing, 22(4), 379-399. doi: 10.1007/s11145-0099162-1

Moats, L., Carreker, S., Davis, R., Meisel, P., Spear-Swerling, L., \& Wilson, B. (2010). Knowledge and practice standards for teachers of reading. Baltimore: IDA.

Nimon, K. (2010). Regression commonality analysis: Demonstration of an SPSS Solution. Multiple Linear Regression Viewpoints, 36(1), 10-17.

NRP (2000). Teaching children to read: An evidence-based assessment of the scientific research literature on reading and its implications for reading instruction. Washington, DC: National Institute of Child Health and Human Development.

OECD (2009). Creating effective teaching and learning environments:
First results from the OECD Teaching and Learning International Survey (TALIS). Paris: OECD.

Seymour, P. H. K., Aro, M., Erskine, J. M., Wimmer, H., Leybaert, J., Elbro, C., ... Olofsson, А. (2003). Foundation literacy acquisition in European orthographies. British Journal of Psychology, 94(2), 143174.

Spear-Swerling, L. (2007). The research-practice divide in beginning reading. Theory into Practice, 46(4), 301-308. doi: 10.1080/00405840701593881

Spear-Swerling, L., Brucker, P. O., \& Alfano, M. P. (2005). Teachers' literacy-related knowledge and selfperceptions in relation to preparation and experience. Annals of Dyslexia, 55(2), 266-296. doi: 10.1007/s11881-005-0014-7

Spear-Swerling, L., \& Cheesman, E. (2012). Teachers' knowledge base for implementing response-to-intervention models in reading. Reading and Writing, 25(7), 1691-1723. doi: 10.1007/s11145-011-9338-3

Sternberg, R. J. (1986). Critical thinking: Its nature, measurement, and improvement. Washington, DC: National Institute of Education.

Sucena, A., Castro, S. L., \& Seymour, P. (2009). Developmental dyslexia in an orthography of intermediate depth: The case of European Portuguese. Reading and Writing, 22(7), 791-810. doi: 10.1007/s11145-0089156-4

Washburn, E. K., Joshi, R. M., \& BinksCantrell, E. S. (2011). Are preservice teachers prepared to teach struggling readers? Annals of Dyslexia, 61(1), 21-43. doi: 10.1007/s11881010-0040-y 
Walsh, K., Glaser, D., \& Dunne-Wilcox, D. (2006). What elementary teachers don't know about reading and what teacher preparation programs aren't teaching. Washington,
DC: National Council for Teacher Quality.

Willingham, D. T. (2007). Critical thinking: Why is it so hard to teach? American Educator, 31(2), 8-19. 
João Lopes holds a Ph.D. in Psychology, and he is a hired Professor in the School of Psychology of the University of Minho. His research interests focuses in the areas of learning disabilities, reading instruction, classroom behavior problems and classroom management. He wrote more than a dozen books on these subjects (e. g. "Behavior problems, learning problems and teaching problems", 2009).

Louise Spear-Swerling, Ph.D., is Professor of Special Education at Southern Connecticut State University in New Haven CT, USA. She has prepared teachers of reading for over three decades. Her research interests include literacy acquisition, reading difficulties, and teacher education. She has published numerous peer-reviewed journal articles and book chapters on these topics, as well as several books, including (with Robert Sternberg) Off Track: When Poor Readers Become "Learning Disabled.

Célia Oliveira holds a PhD in Experimental Psychology (University of Minho). She also holds a Master Degree in Clinical Psychology with a thesis titled "Working Memory in a group of school aged children with ADHD". As a school psychologist she focused on the developmental problems of handicapped children and on the learning problems of school-aged children. She currently teaches Psychology at the O'Porto Lusófona University.

Maria Gabriela Velasquez, Ph.D. in Educational Psychology is currently an elementary teacher. She has an extensive experience both as a teacher educator (preschool and primary teachers) and in the professional development of regular and special education teachers. Her research interests include reading instruction and reading disabilities. She's a member of the Research Center in Psychology of the University of Minho. She co-authored several books on these subjects.

Jamie Zibulsky, Ph.D., is an Assistant Professor of Psychology at Fairleigh Dickinson University. As a school psychologist, she focused on collaborating with teachers and parents to support children's reading acquisition. Her current research focuses on the interaction between early reading skills and behavioral development, as well as teacher professional development efforts in the area of literacy. 
